\title{
PERCEPTION OF LOCAL GEOGRAPHICAL SPECIFICITY BY THE POPULATION OF PODOLIA
}

\author{
Oleksiy GNATIUK \\ Taras Shevchenko National University of Kyiv, Ukraine \\ alexgnat22@ukr.net
}

\begin{abstract}
The article reveals the perception of local geographical specificity by the population of Podolia. Attention is focused on five elements of the local geographical specificity: natural, historical and cultural monuments; prominent personalities; trademarks and producers of goods and services; the origin settlement names; figurative poetic names of settlements. The tasks were the following: to determine basic qualitative and quantitative parameters of regional image-geographical systems, to find the main regularities of their spatial organization, and, finally, to classify administrative-territorial units of the region according to the basic properties of image-geographic systems using specially worked out method. Analysis made it clear that the population of Podolia is characterized by a high level of reflection of the local geographic specificity. Local image-geographical systems from different parts of the region have different structure and level of development. In particular, image-geographical systems in Vinnytsia and Ternopil oblasts are well developed, stable and hierarchized, in Khmelnitskyi oblast it is just developing, dynamic and so quite unstable. To further disclosure the regularities and patterns of local geographical specificity perception, it is advisable to carry out case studies of image-geographic systems at the level of individual settlements.
\end{abstract}

Key words: territorial identity, local geographical specificity, geographic image

UDC: 911.3

\section{СПРИЙНЯТТЯ МІСЦЕВОЇ ГЕОГРАФІЧНОЇ СПЕЦИФІКИ НАСЕЛЕННЯМ ПОДІЛЛЯ}

\author{
Олексій ГНАТЮК \\ Київський національний університет імені Тараса Шевченка, Україна \\ alexgnat22@ukr.net
}

\begin{abstract}
Анотація: У статті розглянуто сприйняття місцевої географічної специфіки населенням Подільського регіону. Увагу зосереджено на п'яти елементах місцевої географічної специфіки: природні та історико-культурні пам'ятки, визначні персоналії, торгові марки, походження назви поселення та образно-поетичні назви поселень і територій. На основі розробленої методики визначено якісні та кількісні параметри образно-географічних систем району, встановлено основні закономірності їх просторової організації, проведено типологію адміністративно-територіальних одиниць регіону за базовими властивостями образно-географічних систем. Виявлено, що населення Подільського регіону характеризується високим рівнем рефлексії місцевої географічної специфіки. Для різних частин регіону властива різна структура та рівень сформованості місцевої образно-географічної системи. Зокрема, образно-географічні системи у Вінницькій та Тернопільській областях $€$ сформованими, усталеними та ієрархізованими. Натомість для образно-географічної системи Хмельницької області властиві протилежні риси, що вказує на її відносну молодість та динамізм. 3 метою подальшого розкриття закономірностей сприйняття населенням місцевої географічної специфіки доцільно проводити дослідження образно-географічних систем окремих поселень.
\end{abstract}

Ключові слова: територіальна ідентичність, місцева географічна специфіка, географічний образ, образно-географічна система

\section{УдК: 911.3}

\section{Introduction}

Territorial identity develops on the basis of the perception of local geographical specificity, i.e. geographical position of the territory (positional properties) and the most characteristic, in particular the unique elements of natural and cultural landscape (attributive properties). These may be topographical, climatic, social, economic, political, historical, cultural, mental local peculiarities etc.

Perception and comprehensive understanding of local geographical specificity result in development of local geographical images and local mythology. Geographical images of the territory may be defined as interrelated and interacting characters, symbols, archetypes and stereotypes, brightly and at the same time simply characterizing certain territory [17, p. 112].

(C) O. Гнатюк
Geographical images and their components constitute the mental space of the territory, i.e. spatially structured image-geographical system. Local mythology may be defined as a system of specific sustainable narratives, common for the local community and regularly reproduced both for internal social and cultural needs and purposeful representations addressed to the external world [16, p. 190]. Together, geographical images and local mythology form the conceptual sphere, comprising a set of cultural and mental structures that mediates individual and collective perception of space [19, p. 61].

Geographical images developed irrelatively to the images of other geographical objects, i.e. solely on the basis of attributive characteristics, are called vertical. Their antipodes are horizontal images arising solely on the basis of positional characteristics. Zamyatina found that purely vertical images are typical for relatively closed and traditional societies, whereas horizontal 
images are more usual for newly explored territories with low rootedness of the population. However, imagegeographical systems of the vast majority of territories combine both vertical and horizontal elements [18; 19; 20].

The system of geographical images and local myths at each specific territory is not something absolutely stable. First, it is changing over time with development of local natural and cultural landscape. Secondly, as noted by Mitin, the process of continuous interpretation leads to the creation of many realities corresponding to one place, so each place may be associated with a variety of images and myths, a set of conceptual layers, and each of them may increase its relative weight in certain conditions $[5 ; 6]$.

Territorial identity, being based exactly on the local context and determining the attitude of the population to the residence place, should be considered as a significant factor of territorial development. Therefore there is a need for detailed study of local specificity perception in different regions of Ukraine.

Analysis of previous researches and publications

Most researchers, which have studied cognitive component of territorial identity, emphasized the importance of geographical environment as a factor that influences on the mentality of territorial communities. Such elements of local geographic specificity as geographical position, topographic, climatic, social, economic, political, historical, cultural and mental peculiarities of the territory have been studied by Raffestin [11], Morozova [7], Smirnova [14], Tishkov [15], Samoshkina [12,p. 17], Gritsenko [2], Goncharik[1,p. 219], Nazukina [9] etc. In particular, Nazukina distinguished different groups of local geographical specificity elements by genesis [8]. Concepts like a geographical local mythology and conceptual sphere have been defined and developed in the works of Zamyatin [16; 17, p. 112] and Zamyatina [18]. Zamyatin elaborated a scheme of the basic concepts describing image-geographical system of a territory [17, p. 113-114], while Zamyatina analyzed differentiation of geographical images into the vertical and horizontal $[18 ; 19 ; 20]$. The concept of aggregated geographic images and myths as a set has been developed in the works of Mitin [5;6]. Also, the perception of local geographic specificity has been studied in different contexts by Krylov [3], Mezentsev and Mezentseva [4], etc. However, there is a need to improve the methods of local specificity research, to identify general regularities of local specificity perception and its interaction with other components of the territorial identity, and, finally, to study the peculiarities of local specificity perception by the population of certain territories.

\section{Study purpose}

The aim of the research is to reveal peculiarities of local geographical specificity perception by the population of Podolia, in particular, to evaluate qualitative and quantitative parameters of regional image-geographical system, establish its level of development, and define basic spatial patterns.

\section{Main material}

Research methodology

This study assessed five elements of local specificity: natural, historical and cultural monuments; prominent personalities; trademarks and producers of goods and services; the origin settlement names; figurative poetic names of settlements. The empirical data were collected by means of questioning (1223 questionnaires) conducted according to previously developed socio-geographic methodic [10].

Podolia we understand here in the borders of Podolian human-geographical region consisting of three Ukrainian administrative oblasts with capitals in Vinnytsia, Kmelnytskyi, and Ternopil. Administrative raion was the basic unit for calculation of indicators. Data for all cities of oblast subordination, including the oblast capitals, were combined with data of the respective surrounding administrative raions. In regard to borderline cities, for this study the city of Ladyzhyn was included in Trostyanets raion and the city of Netishyn was joined to Slavuta raion. These administrative raions hereinafter are called simply «administrative units».

The quality (depth) of local specificity reflection was assessed in two ways:

1. By means of scoring the answers of respondents according to established scale. The sum of all elements of local specificity reflection comprises the integral index of local specificity reflection;

2. By summarizing the ratings of all mentioned images, i.e. popularities of images among the respondents, for each administrative unit.

Based on the data obtained for such components of local specificity as natural, historical and cultural monuments, famous personalities and trademarks, administrative units have been classified according to the following scheme:

1. The first type (Type I) is represented by administrative units with a high sum of image ratings and the presence of several well-known dominating images.

2. The second type (Type II) comprises administrative units with a high sum of image ratings and a single well-known dominating image; in fact, in this case the high summary rating produced by a high rating of dominating image.

3. The third type (Type III) integrates administrative units with a low sum of image ratings and one distinct dominant.

4. The fourth type (Type IV) includes administrative units with a low sum of image ratings and the absence of distinct dominating image.

In addition, such parameters as the rating (frequency) for each geographical image, the dominant image, and the prevalence in rating of the dominating image over the following image have been determined for each local specificity element.

\section{Natural, historical, and architectural landmarks}

In total, respondents indicated 1254 landmarks. Among them, the vast majority comprises architectural monuments, museums, and memorials in honour of prominent personalities and important historical events. Natural landmarks were mentioned much less frequently and are represented by unique landscape features (Podilsky Tovtry, Podolian caves, Dniester River Canyon etc.) or the local rivers (including the largest - Dniester, 
Southern Bug, Zbruch). Other natural objects were mentioned mainly in the context of their historical and cultural values.

In general, the number of landmarks, mentioned by respondents, correlates with their actual number in respective administrative-territorial units (Fig. 1). Therefore the leadership belongs to the major historical cities: Vinnytsia (97) and Ternopil (64). Relatively high number of mentioned landmarks is also observed in the areas of aesthetically appealing and unique landscapes. These areas include the south-eastern corner of Ternopil oblast and the south-west of Khmelnytsky oblast (canyons of the Dniester River and its tributaries, National Nature Park «Podilski Tovtry», Podolian caves), central and north-west parts of Vinnytsia oblast (granite rock exposures along the Southern Bug River and its tributaries).

The ratings (i.e. popularities) of dominating landmarks have a general tendency to decrease from west to east with the highest values recorded in Buchach (Buchach City Hall - 80\%), Pidhaitsi (Assumption Church in Pidhaitsi - 70\%), Kamianets-Podilskyi (Kamianets-Podilskyi Castle - 64.7\%), Kremenets (Holy Dormition Pochayiv Lavra - 60\%), Shepetivka (N. Ostrovsky Museum - 50\%) raions.

Since dominating landmarks play a decisive rule in the perception of local historical and cultural heritage, it is important to analyse them in more detail (see Fig. 2.). The most common group (23) are Christian religious buildings, of which most (in predominantly Orthodox region) are Roman Catholic (14), including in the most eastern Vinnytsia oblast, where the level of polonization and Catholicism imposition was the lowest. This means that Polish-Lithuanian architectural legacy had not just turned into an integral part of the local specificity, but has become a key part that defines the modern perception of the region. Meanwhile, Orthodox Holy Dormition Pochayiv Lavra was the only object of sacral architecture noted in more than one administrative unit.

Fortresses and castles appear to constitute strong perceptive dominants. As a rule, exactly a fortress or a castle was the most popular landmark among respondents (if present within respective territory). Kamianets-Podilskyi Castle, being the most remarkable among these objects, became the absolute leader even in two raions (Kamianets-Podilskyi and Nova Uzhytsia) and, moreover, is perceived as a symbol of Podolia as a region. Fortresses and castles in Zbarazh, Berezhany, Pidvolochysk, Terebovlia, and Medzhybizh also play the role of dominant landmarks. In the absence of preserved castles (mostly in the East of Podolia), palaces and estates often became perceptive dominants, e.g. in Tulchyn, Nemyriv, Khmilnyk, Olhopil, Murovani Kurylivtsi, Zalishchyky, Komarhorod, Nova Obodivka etc.

Civil and industrial architecture monuments play the role of dominant landmarks relatively less than sacred and defensive architecture. Typical examples are city halls in Buchach and Chortkiv, military commissariat in Lypovets, and the Old Mill in Shumsk. Separate group of architectural monuments consists of railway station buildings in Zhmerynka, Koziatyn (though has not become the absolute dominant, was ranked the second), and Derazhnia. While the first two are truly architectural masterpieces, the last one was mentioned as the location of the South-West Railway Museum.

The popular category of monuments are the museums of local lore (in Lityn, Krasyliv, Volochysk, Yampil) and memorial museums, dedicated to important people or events: N. Pirogov in Vinnytsia, M. Ostrovsky in Shepetivka, D. Zabolotny in Zabolotne village (Kryzhopil raion), M. Leontovych in Markivka village (Teplyk raion), The battle of Zboriv, in Zboriv). As a rule, in such cases the person concerned has also become one of the most mentioned outstanding personalities of respective administrative unit.

Sometimes dominant landmarks are represented by the monuments or memorials in honour of famous people or historical events. Typically these are either really outstanding sculptures or the objects located in such important places, as the central squares, parks, public gardens (the value of place transits to the monument, and the image of monument become a key part of the place image). The relationship between monumentalized personality and a particular territory in this case is not important and may be completely absent (e.g., monuments to A. Pushkin in Koziatyn, M. Gogol in MohylivPodilskyi, T. Shevchenko in Borshchiv and Kozova). In the case of the monument to Bohdan Khmelnytsky in the city of Khmelnytskyi such a relationship exists, but indirectly: after renaming the former Proskurov in honour of Bohdan Khmelnytsky, the image of the latter became the part of city image, although the personality of the Hetman in fact had not special relationship to the city.

According to the perception of natural, historical and cultural landmarks, typical examples of Type I territories are large historical cities of Vinnytsia and Ternopil. Territories of Type II are represented by Pidvolochysk, Borshiv, Lityn, Chemerivtsi, Dunayivetsi raions, etc. Territories of Type III are represented by, Buchach, Chortkiv, Derazhnia, Stara Syniava raions. Typical representatives of Type IV are Pishanska, Kryzhopil, Lypovets raions.

\section{Famous personalities}

In total, respondents indicated 448 prominent personalities. Among them 75 were recalled in more than one administrative unit. The absolute record belongs to the three representatives of Vinnytsia oblast: M. Kotsiubynsky (11 units), D. Zabolotny (10 units) and V. Stus (9 units). The list of prominent people includes personalities from different spheres of human activity: writers, military figures, politicians, Church leaders, composers, singers, actors, TV presenters, athletes, scientists, sculptors, folklorists etc. By administrative oblasts, the most popular personalities are M. Kotsyubinsky (Vinnytsia), S. Krushelnytska (Ternopil), V. Ponomarev (Khmelnytskyi). Among dominating personalities our contemporaries comprise $12.5 \%$ in Ternopil oblast, $42.3 \%$ in Vinnytsia oblast and $64.7 \%$ in Khmelnytskyi oblast.

The greatest aggregate ratings of prominent personalities are observed in Ternopil and Vinnytsia with surrounding raions, followed by Monastyryska, Berezhany and Buchach raions. In general, within 


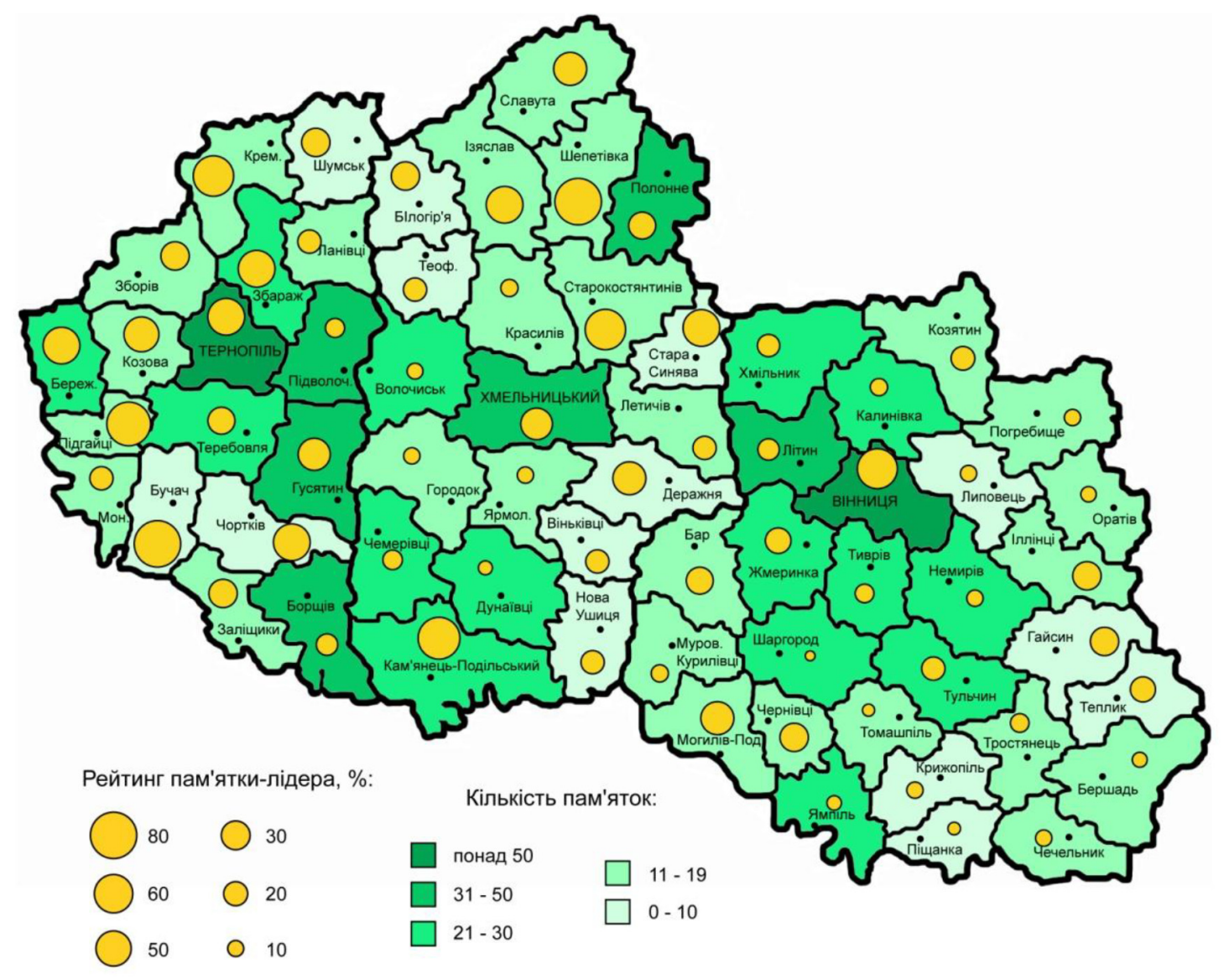

Fig. 1. Natural, historical, and architectural landmarks: quantity of images (ground color) and ratings of dominating images (circle size)

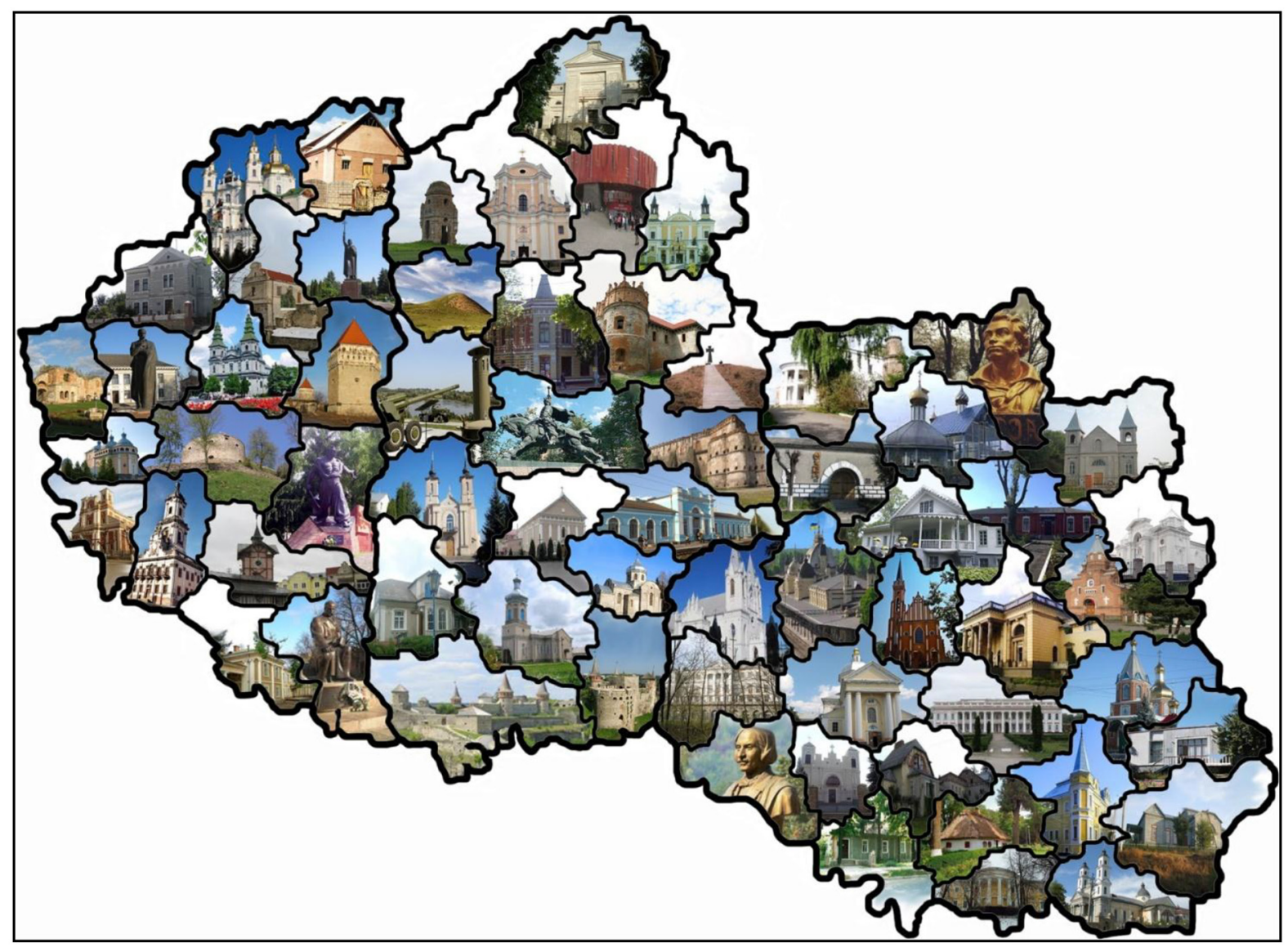

Fig. 2. Dominating natural, historical and cultural monuments 


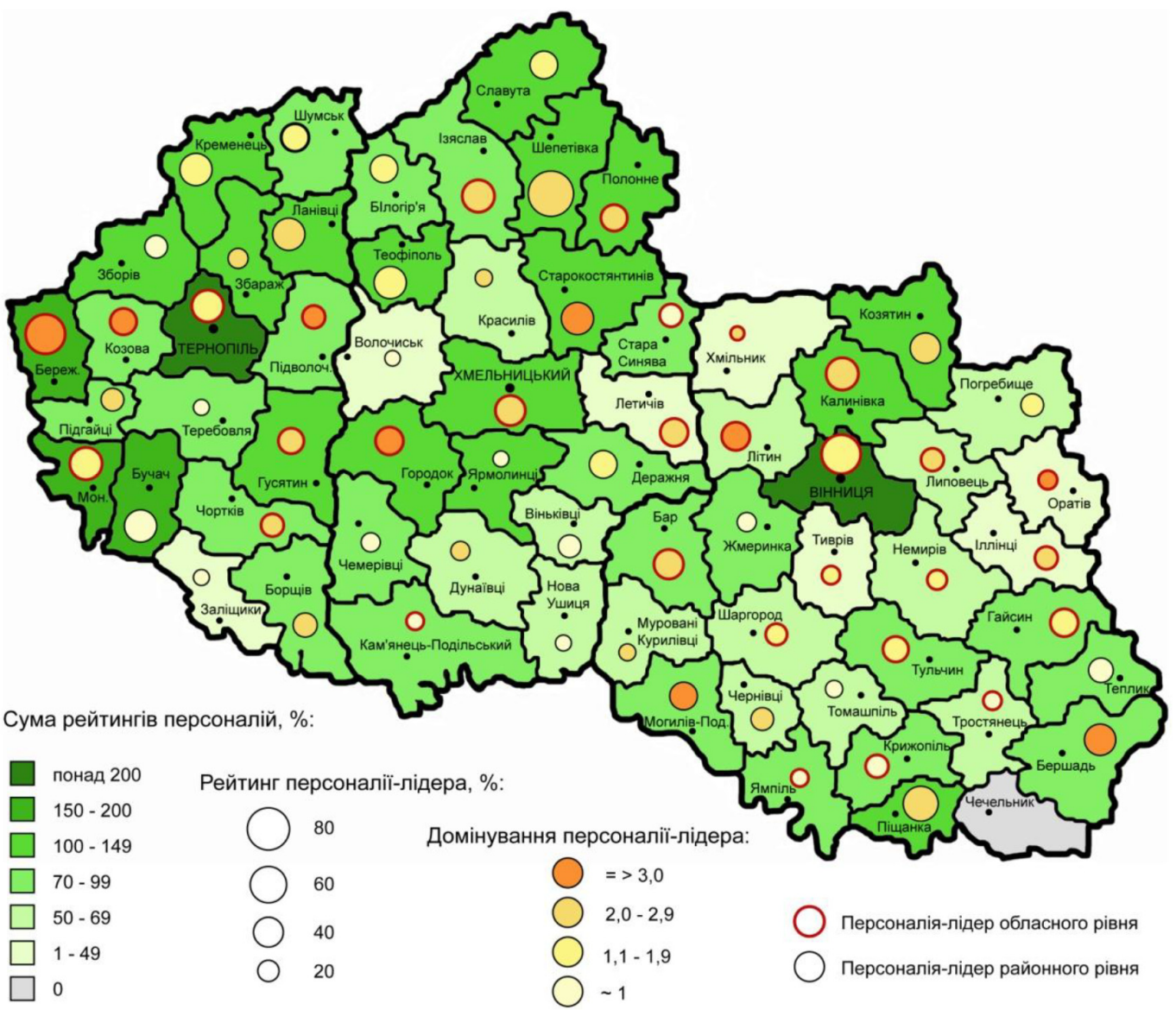

Fig. 3. Famous personalities: aggregate ratings (ground color), ratings of dominating images (circle size), prevalence of dominating image (circle color) and its spatial distribution (circle rim color)

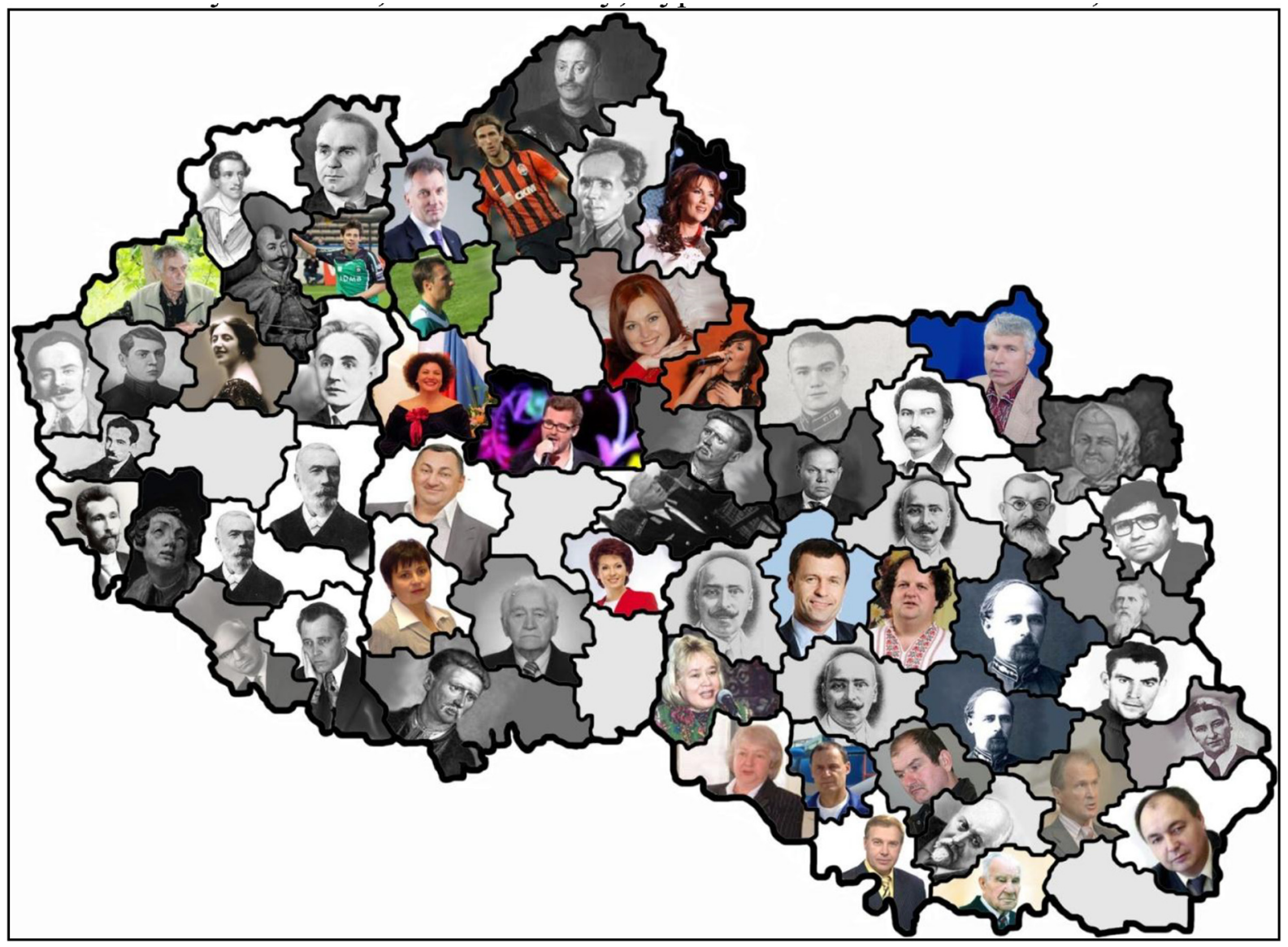

Fig. 4. Dominating prominent personalities 
Podolian region, aggregate ratings tend to decrease from north-west to south-east (Fig.3).

The highest ratings of dominant images are recorded in Shepetivka raion (N. Ostrovsky - 80\%), Vinnytsia (M. Kotsyubinsky - 61.9\%), Berezhany raion (B. Lepky 60\%), Bershad raion (G. Zabolotnyi - 50\%), Pishchanka raion (P. Muravskyi - 47.1\%) districts, Ternopil (P. Krushelnytska - 42,7\%), Kalynivka raion (S. Rudansky $-40,7 \%$ ). The general trend is reducement of this figure from north-west to south-east; low ratings of the dominant personalities also are typical for the southern parts of all three oblasts.

Among dominating personalities 30 are images of the oblast level and were mentioned in more than one administrative unit. Other dominating personalities (34) were mentioned only in one administrative unit, i.e. unknown for a wide range of the population within each oblast, although may have high ratings in one administrative unit (Shepetivka raion - N. Ostrovsky $80 \%$; Buchach raion - I. Pinsel $-40 \%$ ).

Some personalities were rating leaders in several administrative units. For example: M. Kotsiubynsky took the first place in Vinnytsia (both city and raion), Bar and Sharhorod raions. U. Karmaliuk - in KamianetsPodilskyi and Letychiv raions, I. Puluj - in Husiatyn and Chortkiv raions (Fig.4.).

The greatest prevalence in rating (more than 3.0) of the dominating personality over the personality having the second rating was recorded in Berezhany, Kozova, Pidvolochysk, Horodok, Starokostiantyniv, Lityn, Orativ, Mohyliv-Podilskyi, and Bershad raions. At the same time, there are areas where multiple personalities simultaneously have high ratings: the cities of Vinnytsia (M. Kotsiubynsky and N. Pirogov) and Ternopil (S. Krushelnytska and S. Prytula), and also Monastyryska raion (V. Hnatiuk and B. Lepky).

On the map, the portraits of our contemporaries are presented in color, and of those who decease - in blackand-white.

Almost all the administrative units of Ternopil oblast (except Zalishchyky raion) belong to Types I and II, and there are no units belonging to Type IV. Units with a clear identifiable dominant account for almost a half. In Khmelnitsky oblast there is a prevalence of Type I and IV units, i.e. without explicit dominant (65\%), while in Vinnytsia oblast, on the contrary, Types II and III account for $70,4 \%$.

\section{Trademarks}

Totally respondents indicated 213 trademarks, among them 65 trademarks mentioned in more than one administrative unit. The absolute record for the spatial covering belongs to the trademarks of Vinnytsia and Ternopil oblasts: «Roshen» (22 units), «Molokiya» [Молокія] and «Karavan» [Караван] (14 units), «Nemiroff» (13 units), «Avis» [Aвic] (12 units), «Tulchinka» [Тульчинка] (11 units). «Roshen», «Molokiya» [Молокія] and «Nasoloda» [Насолода] are the leaders in terms of absolute number of respondents indicating a particular trademark in Vinnytsia, Ternopil and Khmelnytskyi oblasts, respectively.

The greatest aggregate ratings of trademarks mentioned (over 150\%) were recorded in the cities of Ternopil and Vinnytsia with surrounding raions, as well as in Iziaslav raion. In general, this indicator within Podolian region depends on purely local specifics, primarily the presence of such local trademarks (Fig.5).

Exactly a half of dominant trademarks are local by origin (i.e. manufacturer is located in a given administrative unit). In Khmelnytskyi oblast such local dominant trademarks make up the majority $(60.0 \%)$, while in Ternopil oblast they comprise 47.1\%, and in Vinnytsia oblast only $44.0 \%$. There are many administrative units (11) without mentioned local trademarks. By contrast, in other administrative units all mentioned trademarks occurred to be local.

The highest ratings of dominant trademarks were recorded in Nemyriv («Nemiroff» - 85.0\%), Tulchyn («Tulchinka» [Тульчинка] - 85.0\%), Vinkivtsi («Vinkivchanka»[Віньківчанка] - 70.0\%), Bar («Barchanka» [Барчанка] - 63.3\%), Slavuta («Sangushko» [Сангушко] - 60.0\%), Mogyliv-Podilskyi («Vatsak» [Вацак] - 60.0\%) raions and the city of Vinnytsia («Roshen» - 58.7\%). On the whole, these figures increase from west to east: Ternopil oblast has no dominant trademark with a rating of more than $50 \%$, Khmelnytskyi oblast has 2 such trademarks and in Vinnytsia oblast they account for 6 . Trademarks with the highest rating are mainly well-known, therefore actually form the image of corresponding administrative unit and may displace the images of local, less known trademarks in other administrative units. Trademarks that have been mentioned in only one administrative unit comprise a relatively minor part among the dominant trademarks. As a rule, their ratings are low; however, there are some exceptions: beer «Sangushko» [Сангушко] (Iziaslav raion), cognac «Buchach» [Бучач] (Buchach raion) etc.

Some trademarks dominant in several administrative units. For example, «Roshen» took first place in 12 raions of Vinnytsia oblast and the city of Vinnytsia, «Molokiуа» [Молокія] - in 6 districts of Ternopil oblast and the city of Ternopil, «Zbruchanska» [Збручанська] - in Husiatyn and Horodok raions.

The greatest prevalence in rating (more than 3.0) of the dominant trademark over the following one was recorded in Berezhany, Kozova and Pidvolochysk raions of Ternopil oblast, Horodok and Starokostyantyniv raions of Khmelnytskyi oblast, Lityn, Orativ, MogylivPodilskyi, and Bershad raions of Vinnytsia oblast. Meantime, there are areas where multiple trademarks have a high rating, so the difference between the first and second place is small: the city of Vinnytsia («Roshen» and «Avis» [Aвic]), Bar («Barchanka» [Барчанка] and «Verkhivska Perlyna» [Верхівська перлина]), Mogyliv-Podilskyi («Vatsak» [Вацак] and «Bronychanka» [Броничанка]) raions, etc.

Administrative units of Type I constitute the absolute majority in Vinnytsia oblast (59.3\%) and relative majority in Ternopil oblast (47.1\%), as within Podolian region in whole (46.9\%). But in Khmelnytskyi oblast they give way to the units of Type IV (30.0\% vs. $35.0 \%)$.

\section{The origin of settlement name}

More than $85 \%$ of respondents noted that they know the origin of their settlement name. Different 


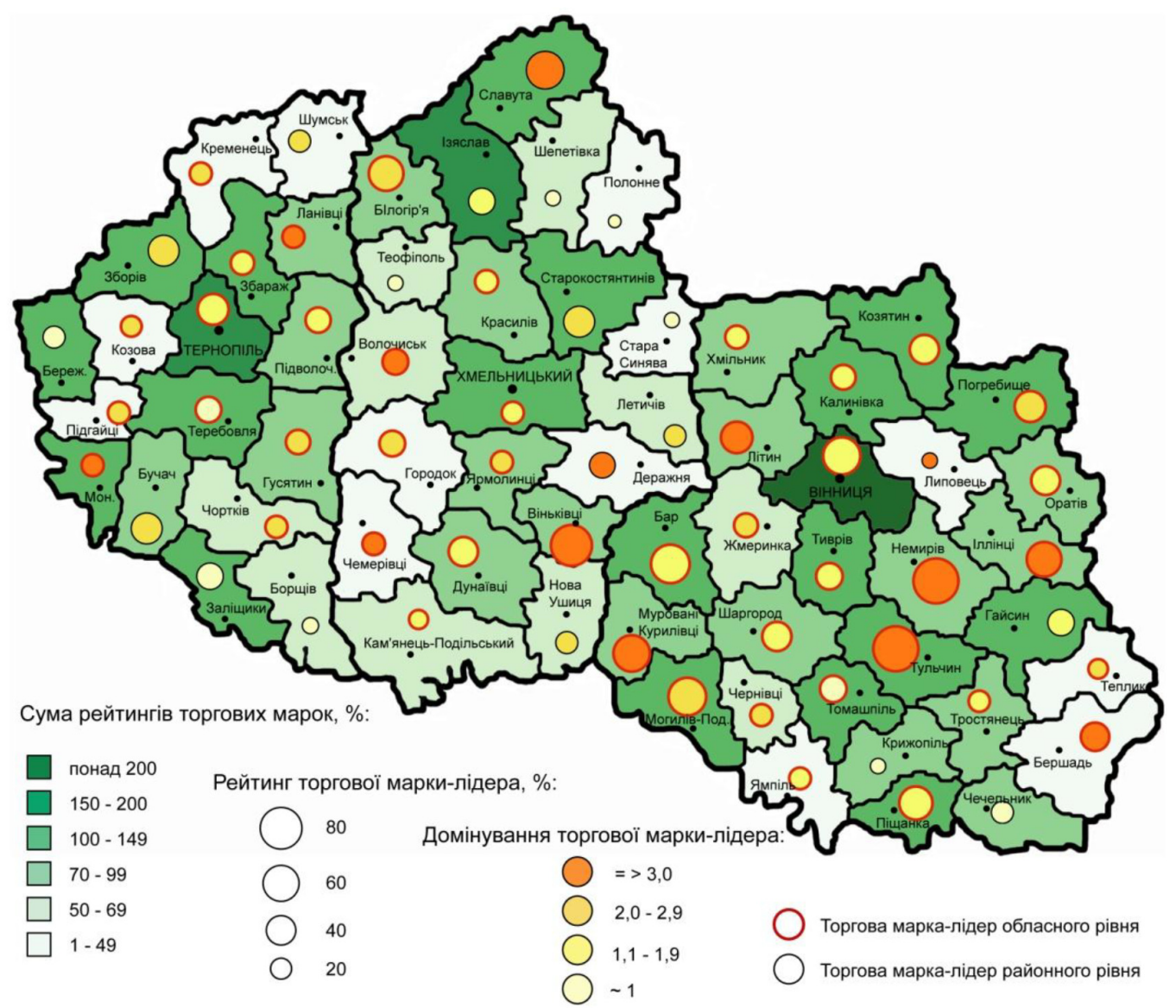

Fig. 5. Trademarks: aggregate ratings (ground color), ratings of dominating images (circle size), prevalence of dominating image (circle color) and its spatial distribution (circle rim color)

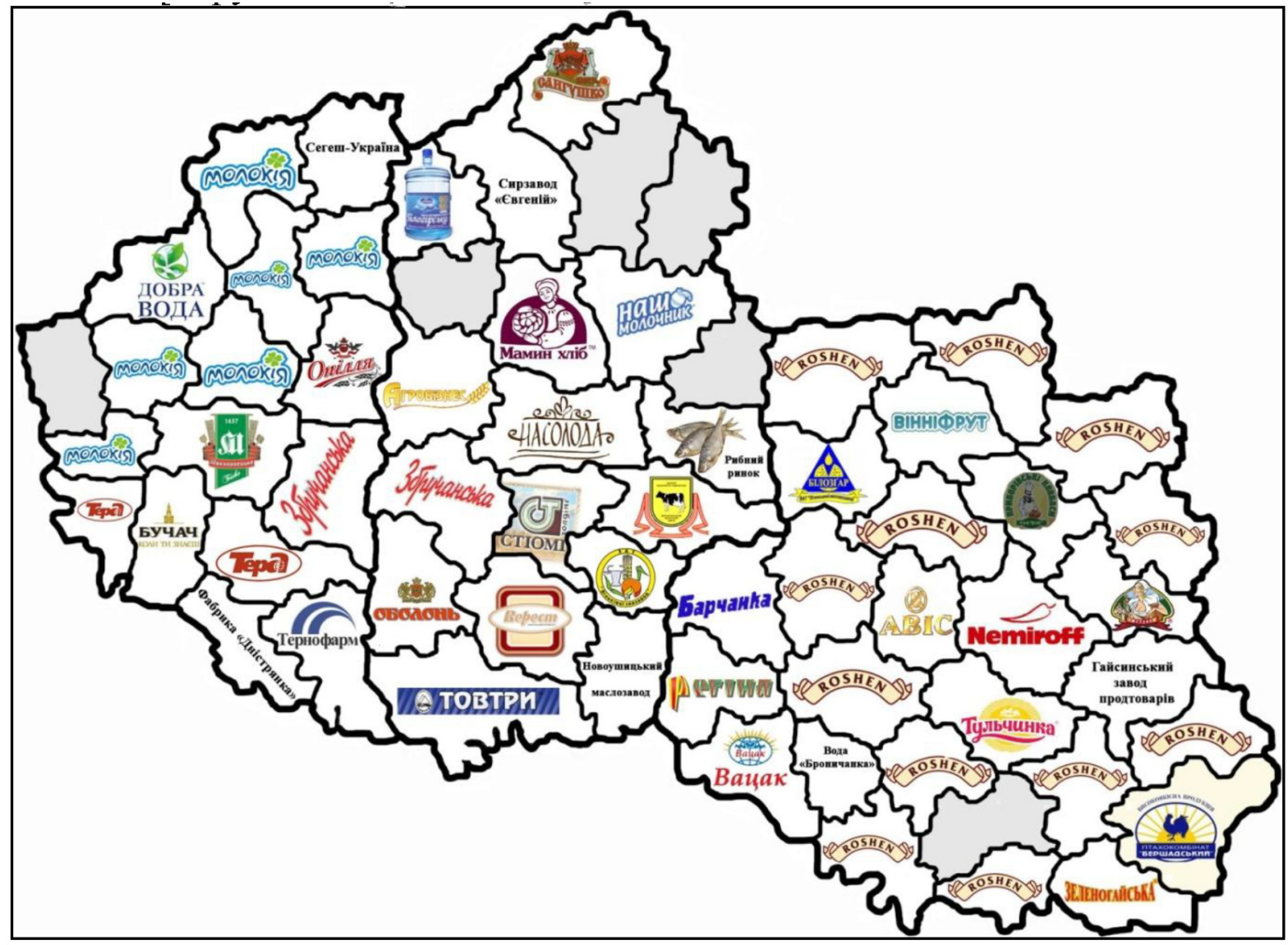

Fig. 5. Dominating trademarks 


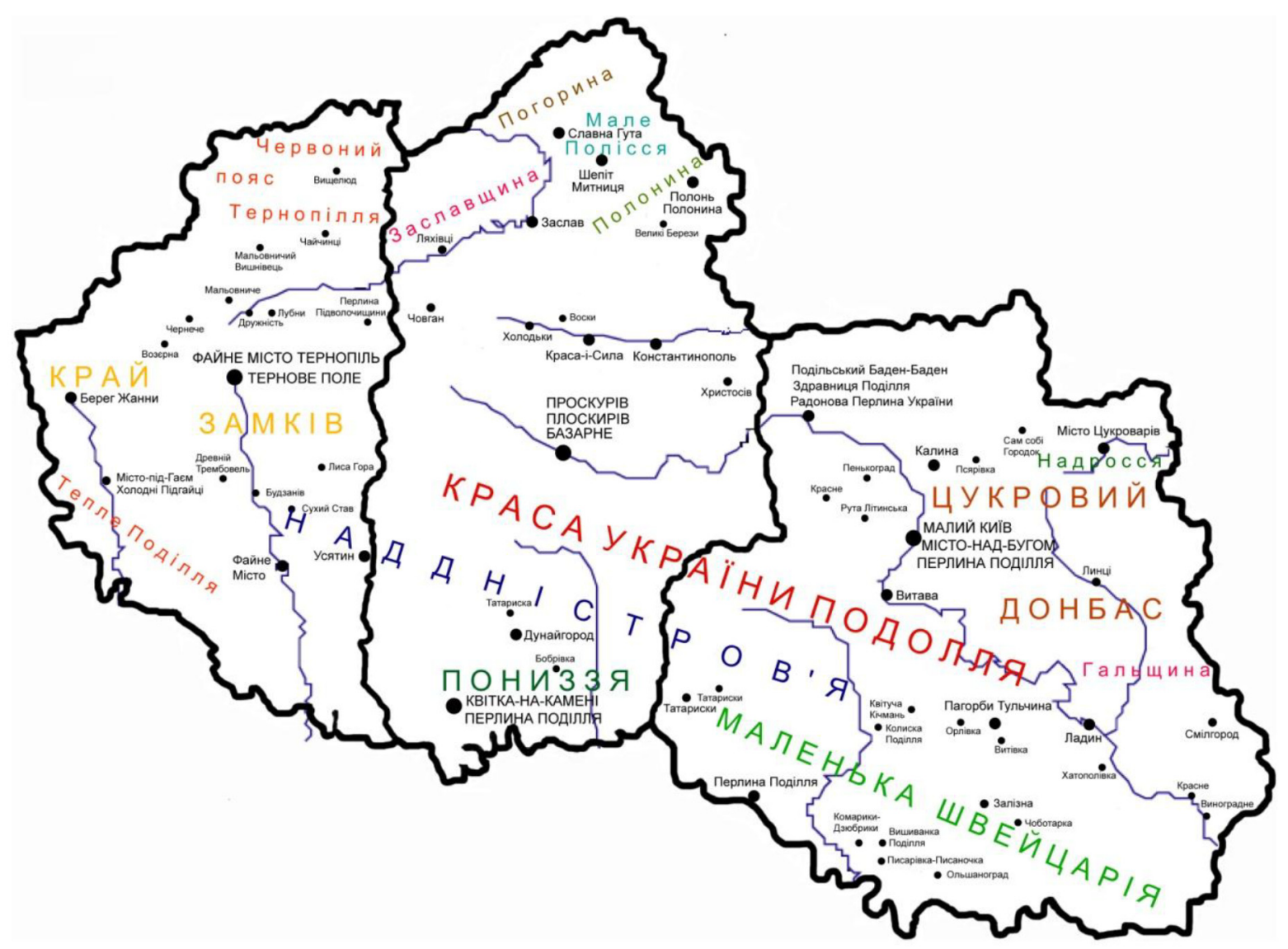

Fig. 7. Figurative poetic names (in Ukrainian)

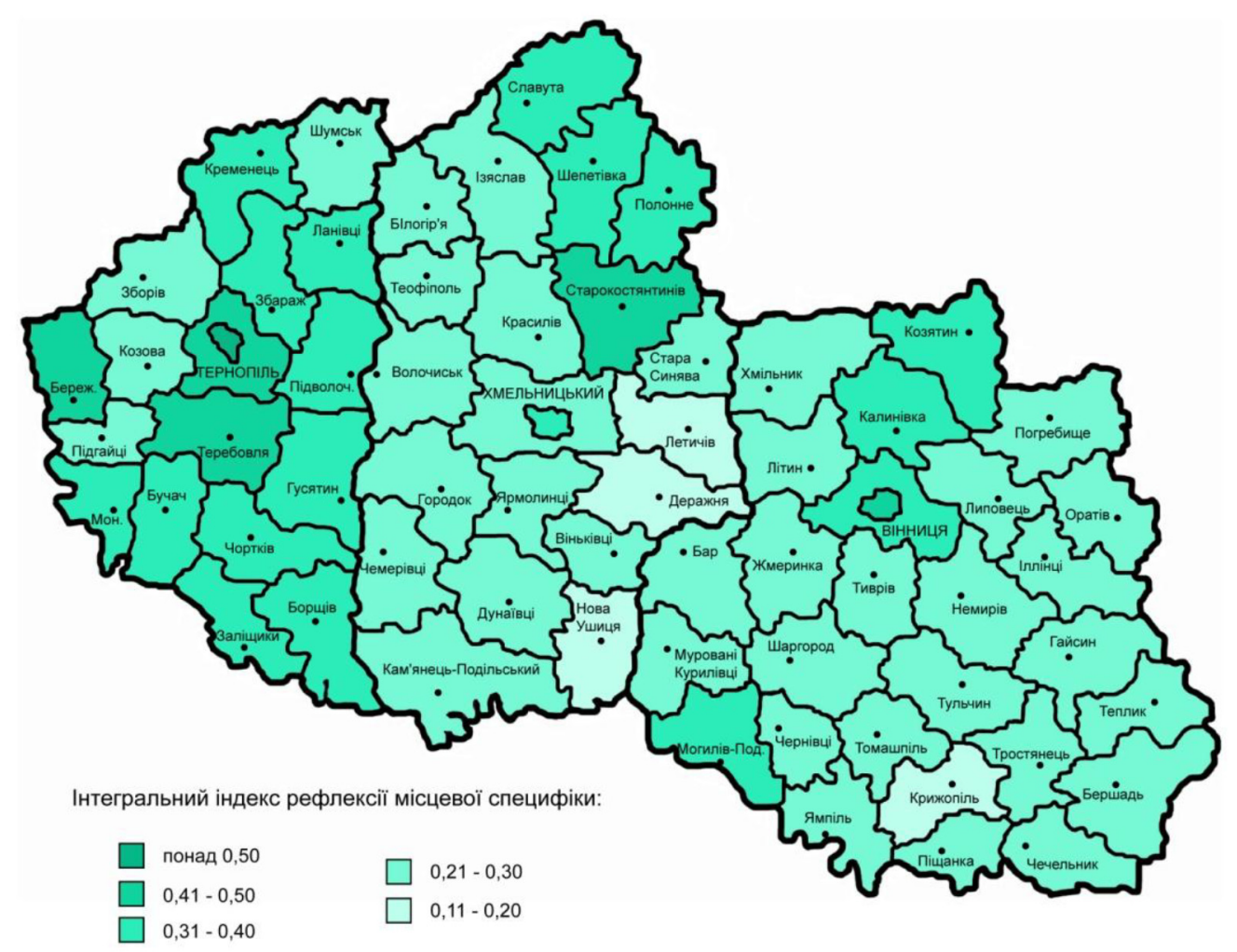

Fig. 8. Integral index of local specificity reflection 
respondents often gave different versions for the same settlement, among them were both scientifically proven and folk etymology versions, the latter based on local folklore (tales, legends, epics, etc.). This folklore should be considered as an essential part of the local mythology. If the settlement changed its name in the past, this fact is almost always widely known to local people, even young.

\section{Figurative poetic names}

The study detected three groups of figurative poetic names. The first group includes names given to the large areas, comprising one or more administrative oblasts. These names usually reflect historical and geographical belonging of territory («Podolia the Beauty of Ukraine»), its geographical location (areas within Vinnytsia, Khmelnytskyi and Ternopil oblasts, adjacent to the valley of the Dniester, are called «Naddnistrovya», southern part of Khmelnytskyi oblast has a name «Ponyzzia»), specifics of the natural and cultural landscape (Vinnytsia oblast - «Little Switzerland», Ternopil oblast - «The Land of Castles»), economic specialization (Vinnytsia oblast - «Sugar Donbass»). Typically, these names emphasize the beauty and scenery of local landscape.

The second group includes names given to relatively small areas and emphasize belonging to the river basins («Pohoryna» in the basin of Horyn, «Nadrossia» in the basin of Ros), local landscape features («Small Polesia»), climatic features («Warm Podolia»), confessional and/or electoral characteristics («Red belt of Ternopil region»), areas of historical cities influence («Zaslavshchyna» - around Iziaslav, «Polonyna» - around Polonne, «Halshchyna» - around Haisyn).

The third group includes the names of individual settlements. These names may be based on the following:

1. Historical name of the settlement: «Proskuriv» (now Khmelnytskyi), «Vienicha» (now Vinnytsia), «Zaslav» (now Iziaslav), «Vytava» (now Hnivan), «Liakhivtsi» (now Bilohirya), «Usiatyn» (now Husiatyn) etc.

2. Making play with pronunciation, phonetic sound of the settlement name:

A) Purely poetic, often reflecting the folk etymology: «Bereh Zhanny» [Берег Жанни], meaning «The Coast of Jeanne « (Berezhany), «Ternove Pole» [Тернове Поле], meaning «Thorns Field» (Ternopil), «Krasa-i-Syla» [Краса-i-Сила], meaning «Beautyand-Power» (Krasyliv), «Ladyn» [Ладин], meaning «belonging to Lada» (Ladyzhyn), «Славна Гута» (Slavuta), «Constantinople» (Starokostiantyniv), «Misto pid Hayem» [Місто під Гаєм], meaning «The City near the Grove» (Pidhaytsi), etc.

B) Humorous, more often in rural settlements: «Sam-sobi-Horodok» [Сам-собі-Городок], meaning «Little Town of Itself» (Samhorodok), «KomarykyDziubryky» [Комарики-Дзюбрики] from Ukrainian folk song (Dziubrove); sometimes rural place names are styled on the order of «respectable» city names: «Penkohrad» [Пенькоград], meaning «The City of Tree Stubs» (Penkivka), «Olshanohrad» [Ольшаноград] (Vilshanka); rarely in the cities, e.g. «Shepit» [Шепіт], meaning «Whisper» (Shepetivka).

3. Geographical location: «The City upon Bug» (Vinnytsia), «The City on the Stone» (Kamianets Podilskyi).

4. Local climate pattern: «Cold Pidhaitsi» (Pidhaitsi)

5. Local folk arts and crafts: «Pysarivka-Pysanochka» [Писарівка-Писаночка], meaning «Pysarivka - painted Easter egg» (Pysarivka), «Podolian Vyshyvanka» [Вишиванка Поділля], meaning «Podolian embroidered shirt» (Klembivka),

6. Specificities of economic activities: «The City of Sugar Refiners» (Pohrebyshche), «Podolian BadenBaden», «Radon Pearl of Ukraine», «Podolian Resort» (all about Khmilnyk), «Customs» (Shepetivka, a border city and a rail junction in early Soviet Union period); sometimes an ironic reflection: «Market» (Khmelnytskyi).

7. Statements made in literary works or by historical figures: «Hills of Tulchyn» (Tulchyn, based on the novel «Eugene Onegin» by A. Pushkin), «Iron» (Vapniarka, in the words of Colonel V. Tiutiunnyk).

8. Expression of favorable attitude to the settlement:

A) Accentuation the uniqueness and importance of the settlement for the region: «The Pearl of Podolia» (Vinnytsia, Kamianets-Podilskyi, Mohyliv-Podilskyi), «The Capital of Podolia» (Vinnytsia), «The Cradle of Podolia» (Dzhuryn), «The Pearl of Pidvolochyshchyna» (Koshliaky).

B) Comparison with other settlement: «Little Kyiv» (Vinnytsia), «Podolian Baden-Baden» (Khmilnyk).

C) Simple statement of favorable attitude: «Fine City of Ternopil» [Файне місто Тернопіль] (Ternopil), «Fine City» [Файне місто] (Chortkiv).

Figurative poetic names, detected during the study, have been reflected at the map (Fig. 7) that may be considered as «alternative map» for studied region existing in the minds of people.

The highest integral index of local specificity reflection is observed within Ternopil oblast. Especially high integral index within Podolian region are typical for historical urban settlements, e.g., Ternopil, Vinnytsia, Berezhany, Terebovlia, Starokostiantyniv etc. (Fig. 8).

Internal differences of image-geographical system within Podolian region

In different parts of Podolia, images of different kinds play a leading role. By the criteria of the dominant image rating, natural, historical and cultural monuments represent the absolute dominant in $36 \%$ of the administrative units, trademarks - also in $36 \%$, and personalities - in 28\% (Fig.9). There is an approximate parity in terms of aggregate numbers, but clear spatial trends are observed within the studied region. The relative significance of monuments rapidly decreases from west to east (Ternopil oblast $-58.8 \%$, Khmelnytskyi oblast - 50.0\%, Vinnytsia oblast $11.1 \%$ ), but the opposite situation we have in the case of trademarks $(11.8 \%, 25.0 \%$, and $59.3 \%$, respectively). The relative value of the outstanding personalities among dominating images are almost identical everywhere (from $25.0 \%$ in Khmelnytskyi oblast to $29.6 \%$ in Vinnytsia oblast). The reasons for these patterns are the following: 1 . high concentration and preservation 


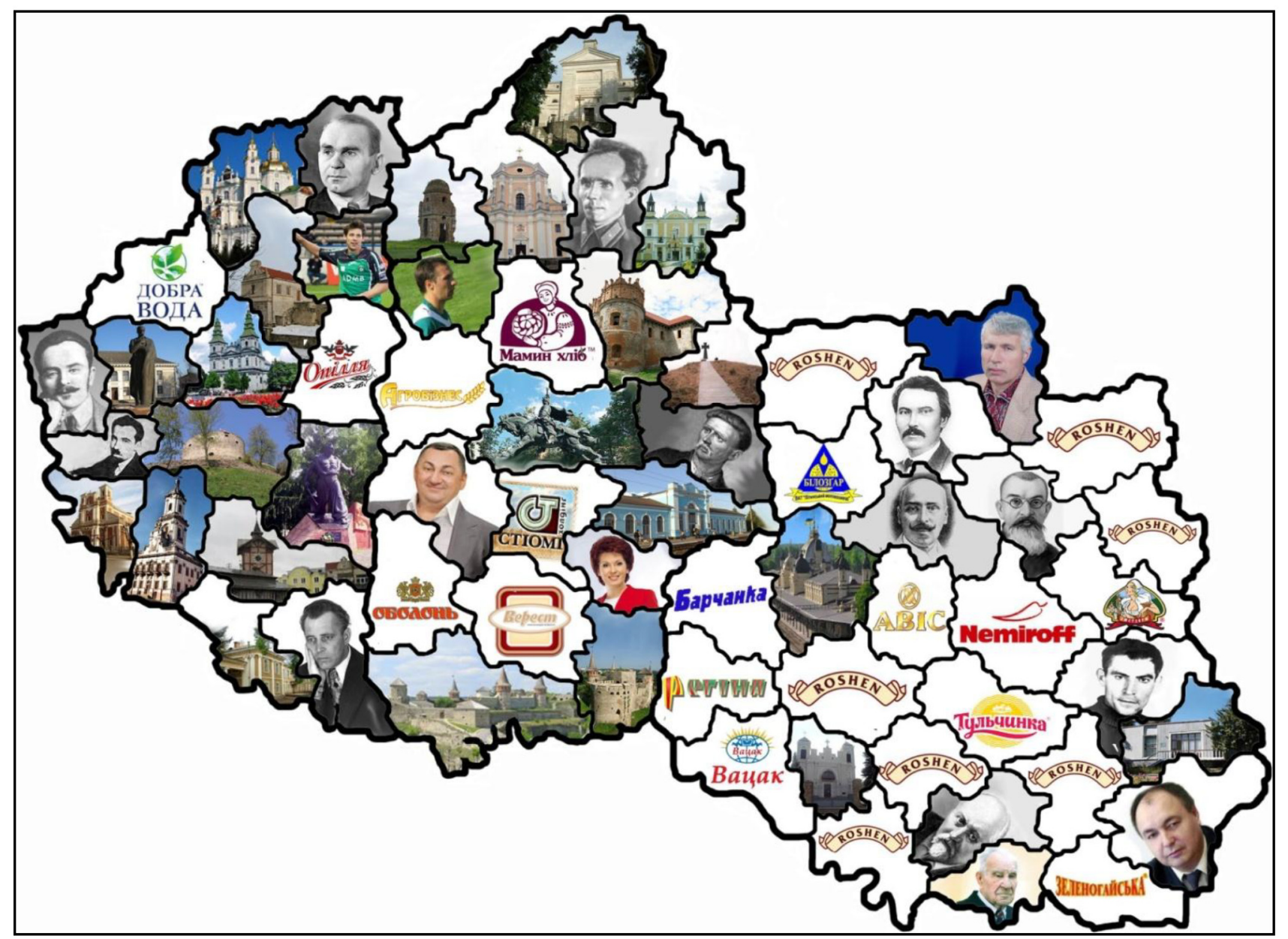

Fig. 9. Absolute dominants

level of historical and cultural monuments in the Western part of Podolia; 2. high concentration of product manufacturers that own well-known trademarks in the eastern part of Podolia; 3. as a hypothesis, the higher level of public interest in the Western Podolia in local historical and cultural heritage as a manifestation of the strongest local and national patriotism.

Administrative units belonging to Types II and III have one distinct dominant among local geographical images, which subjugates the other geographical images and myths, structuring in this manner territorial imagegeographical system. Mental space of such areas is well structured and conservative, but strongly depends on the state of the dominating images. Since the territories of the Type II has a significant amount of strong images, the weakening or disappearance of the dominant image will increase the ratings of its competitors, but also lead to the transformation of the entire image-geographical system in line with the new dominant image. At the same time on the territories of Type III, voiding a significant reserve of geographical images, the disappearance of the dominant image would have a destructive impact on entire image-geographical system. Mental space of administrative units belonging to the I Type, as a rule, is well-structured with several dominating images at the highest level of hierarchy. The loss of one dominating image may be simply compensated by the strengthening of the other, so adaptation of image-geographic system may proceed relatively easy; in process of its development leading images may periodically replace each other. Units of Type IV have no distinct dominant images, so the loss of one particular image does not significantly affect the hierarchy of image-geographical system but has a high destructive role due to the small total number of images. Image-geographical systems of such areas exist at an early stage of formation and are very vulnerable.

Image-geographic systems in Vinnytsia and Ternopil oblasts are well developed, stable and hierarchized, which is reflected in the following signs:

1. Presence of symbolic images that are well known through the entire respective oblast.

2. Presence of images dominating in a large number of administrative units.

3. Clear hierarchy of images, including significant predominance of dominant images over the competitors.

4. Dominance of images relating to longstanding objects (by the time of occurrence or existence).

These peculiarities contribute to the growth of the share of administrative units belonging to the Types I, II and III.

On the contrary, the following signs indicate instability and dynamism of image-geographical system in Khmelnytskyi oblast:

1. The lack of symbolic images that are well known 
through the entire oblast: the vast majority of images are known only to the people from separate administrative units.

2. The lack of images dominating in a large number of administrative units. Each territory has its own dominant, associated with a purely local context.

3. The absence of a clear hierarchy of images that often leads, among other consequences, to the lack of clearly defined dominant. The current ratings of dominant images are very close to the ratings of their nearest competitors, so in the near future the situation may change.

4. The prevalence of modern images, i.e. those that relate to the objects that recently occurred or existed. This is clearly seen in the analysis of the images of prominent personalities as dominance of contemporaries, whose contribution to public life may be repeatedly reviewed in the near future.

All these features lead to a greater diversity of images, both territorial and structural (within separate administrative unit), and the dynamism of the entire image system and their hierarchy, as well as to the predominance of administrative units belonging to the Types I and IV.

\section{Conclusions}

1. Population of Podolia has demonstrated a high degree of local geographical specificity reflection, indicating thousands of local geographic images and hundreds of local myths. Respondents always tried to find some unique objects within the surrounding territory, even if such objects have no outstanding social, cultural or historical value and remain unknown for a vast majority of Ukrainians.

2. Different areas within Podolian region have different structure of the local image-geographical system with predominance of either monuments, or outstanding personalities, or trademarks. The specific ratio of individual geographic specificity elements in the perception can be explained by both real spatial diversity of the geographical specificity and local values and amenities.

3. Image-geographical systems of Podolian region differ by total number of geographical images, depth of their perception and prevalence of dominant images, which affects persistence and stability of their internal hierarchical structure.

4. Image-geographical systems have different levels of development and stability in various areas within Podolia. While in Vinnytsia and Ternopil oblasts they are quite well developed, stable and hierarchized, in Khmelnitskyi oblast it is just developing, dynamic and so should be quite unstable.

5. To further disclose the laws and patterns of local geographical specificity perception, it is advisable to conduct studies of geographical image systems at the level of individual settlements. In addition to the theoretical significance, such studies will be of great practical importance in the context of territorial sustainable development and rational use of local symbolic resources.

\section{References:}

1. Gončarik A. A. Issledovanie regional'noj identičnosti nacional'noj okrainy [The study of regional identity at national periphery]. Identičnost' kak predmet političeskogo analiza [Identity as a subject of political analysis]. Moscow, 2011, pp. 219-224. (In Russian).

2. Gricenko A. A. Rossijsko-ukrainskoe porubeže i regional'naâ identičnost' v Kurskoj oblasti [RussianUkrainian borderline and regional identity in Kursk oblast]. Gumanitarnye resursy kul'urnogo razvitiâ (na primere estestvenno-prirodnogo i kul'turnogo naslediâ). [Humanitarian resources for cultural development (example of natural and cultural heritage)]. Moscow, 2009, pp. 355-364. (In Russian).

3. Krylov M. P. Regional'naâ identičnost' evropejskoj Rossii [Regional identity is European Russia]. Moscow, 2010, 240 p. (In Russian).

4. Mezenceva N., Mezencev K. Percepcìnì portreti regìonìv Ukraïni [Perceptual portraits of Ukrainian regions]. Regional'nì problemi Ukrä̈ni: geografičnij analìz ta pošuk šlâhìv virišennâ [Regional problems of Ukraine: geographical analysis and search for solutions,]. Kherson, 2005, pp. 208-213. (In Ukrainian).

5. Mitin I. I. Mifogeografiâ kak podhod k izučeniû množestvennyh real'nostej mesta [Mythogeography as an approach to studying multiple realities of space]. Gumanitarnaâ geografiâ: Naučnyj i kul'turno-prosvetitel'skijal'manah [Humanitarian geography: Scientific, cultural and educational almanac], 2006, Vol. 3, pp. 64-82. (In Russian).

6. Mitin I. I. Na puti k mifogeografii Rossii: «igry s prostranstvom» [On the way to mythogeography of Russia: «playing with space»]. Vestnik Evrazii [Bulletin Of Eurasia], 2004, Vol. 3, pp. 140-161. (In Russian).

7. Morozova E. V., Ul'ko E. V. Lokal'naâ identičnost': formy aktualizacii i tipy [Local identity: forms of actualization and types]. POLITĖKS [Political Expertise], 2008, Vol. 4, pp. 139-151. (In Russian).

8. Nazukina M. V. Regional identity [Regional identity]. Političeskấ identičnost' i politika identičnosti [Political identity and the policy of identity], Moscow, 2011, Vol. 1, pp. 143-147. (In Russian).

9. Nazukina M. V. Regional'naâ identičnost' v sovremennoj Rossii: tipologičeskij analiz [Regional identity in modern Russia: a typological analysis]. Author's abstract of PhD Thesis. Perm, 2009, 26 p. (In Russian).

10. Olìjnik Â. B., Gnatûk O. M. Metodičnì pìdhodi do doslìdžennâ teritorìal'noï ìdentičnostì naselennâ [Methodological approaches to the study of territorial identity of population]. Ukrä̈ns'kij geografičnij žurnal [Ukrainian geographical journal], 2013, Vol. 3, pp. 34-39. (In Ukrainian).

11. Raffestin C. Immagini e identità territoriali. Il mondo e i luoghi: Geografie dell'identità e del cambiamento. Piemonte, 1983, pp. 3-11. (In Italian). 
12. Samoškina I. S. Territorial'naâ identičnost' kak social'no-psihologičeskij fenomen [Territorial identity as a socio-psychological phenomenon]. Author's abstract of PhD Thesis. Moscow, 2008, 29 p. (In Russian).

13. Sliz A., Ŝepanskij M. S. Lokal'naâ i regional'naâ identičnost' v processe globalizacii [Local and regional identity in the globalization process]. Vestnik SevGTU [Bulletin of Sevastopol State Technical University], 2009, Vol. 94, pp. 3-7. (In Russian).

14. Smirnova N. A. Regional'naâ identičnost' v usloviâh sovremennogo rossijskogo obŝestva [Regional identity in the modern Russian society]. Author's abstract of PhD Thesis. Volgograd, 2004, 27 p. (In Russian).

15. Tiškov V. A. Tri karty [Three maps]. Access mode: http://valerytishkov.ru/cntnt/novye_publikacii/vatishkov_. html. (In Russian).

16. Zamâtin D. N. Identičnost' i territoriâ: gumanitarno-geografičeskie podhody i diskursy [Identity and territory: humanitarian-geographical approaches and discourses]. Identičnos' kak predmet političeskogo analiza [Identity as a subject of political analysis]. Moscow, 2011, pp. 186-203. (In Russian).

17. Zamâtin D. N. Soprostranstvennost' i identičnost' [Co-spatiality and identity]. Mir psihologii [World of psychology], 2012, Vol. 69, pp. 104-123. (In Russian).

18. Zamâtina N. U. Problemnoe pole territorial'noj identičnosti v kontekste organizacii i samoorganizacii social'nyh struktur [The problem field of territorial identity in the context of organization and self-organization of social structures]. Mir psihologii [World of psychology], 2012, Vol. 69, pp. 123-137. (In Russian).

19. Zamâtina N. Û. Smysl položeniâ: mesto v mental'no-geografičeskih prostranstvah [Sense of location: a place in mental-geographical spaces]. Meždunarodnyj žurnal issledovanij kul'tury [International journal of cultural studies], 2011, Vol. 4 (5), pp. 60-68. (In Russian).

20. Zamâtina N. U. Territorial'naâ identičnost': tipy formirovaniâ i obrazy territorii [Territorial identity: types of development and territorial images]. Identičnost' kak predmet političeskogo analiza [Identity as a subject of political analysis]. Moscow, 2011, pp. 203-212. (In Russian). 